\title{
Electrochemical Glucose Oxidation Using Glassy Carbon Electrodes Modified with Au-Ag Nanoparticles: Influence of Ag Content
}

\author{
Nancy Gabriela García-Morales, ${ }^{1}$ Luis Alfonso García-Cerda, \\ Bertha Alicia Puente-Urbina, ${ }^{2}$ Leonor María Blanco-Jerez, ${ }^{3}$ \\ René Antaño-López, ${ }^{1}$ and Federico Castañeda-Zaldivar ${ }^{1}$ \\ ${ }^{1}$ Centro de Investigación y Desarrollo Tecnológico en Electroquímica, Parque Tecnológico Querétaro, s/n, \\ Sanfandila, 76703 Pedro Escobedo, QRO, Mexico \\ ${ }^{2}$ Centro de Investigación en Química Aplicada, Bulevar Enrique Reyna 140, Colonia San José de los Cerritos, \\ 25294 Saltillo, COAH, Mexico \\ ${ }^{3}$ Laboratorio de Electroquímica, Facultad de Ciencias Químicas, Universidad Autónoma de Nuevo León, \\ Guerrero y Progreso, s/n, Colonia Treviño, 64570 Monterrey, NL, Mexico
}

Correspondence should be addressed to Federico Castañeda-Zaldivar; fcastaneda@cideteq.mx

Received 12 May 2015; Revised 10 July 2015; Accepted 28 July 2015

Academic Editor: Xin Zhang

Copyright (C) 2015 Nancy Gabriela García-Morales et al. This is an open access article distributed under the Creative Commons Attribution License, which permits unrestricted use, distribution, and reproduction in any medium, provided the original work is properly cited.

\begin{abstract}
This paper describes the application of glassy carbon modified electrodes bearing $A u_{x}-A_{y}$ nanoparticles to catalyze the electrochemical oxidation of glucose. In particular, the paper shows the influence of the Ag content on this oxidation process. A simple method was applied to prepare the nanoparticles, which were characterized by transmission electron microscopy, Ultraviolet-Visible spectroscopy, X-ray diffraction spectroscopy, and cyclic voltammetry. These nanoparticles were used to modify glassy carbon electrodes. The effectiveness of these electrodes for electrochemical glucose oxidation was evaluated. The modified glassy carbon electrodes are highly sensitive to glucose oxidation in alkaline media, which could be attributed to the presence of $\mathrm{Au}_{x}-\mathrm{Ag}_{y}$ nanoparticles on the electrode surface. The voltammetric results suggest that the glucose oxidation speed is controlled by the glucose diffusion to the electrode surface. These results also show that the catalytic activity of the electrodes depends on the Ag content of the nanoparticles. Best results were obtained for the $\mathrm{Au}_{80}-\mathrm{Ag}_{20}$ nanoparticles modified electrode. This electrode could be used for Gluconic acid (GA) production.
\end{abstract}

\section{Introduction}

Glucose electrooxidation, specifically on Au electrodes, has been extensively studied because it is a reaction of scientific and industrial interest [1-11]. Due to the high catalytic activity of modified electrodes bearing nanoparticles, $\mathrm{Au}$ nanoparticles have been studied for glucose fuel cells [1214], for degradation of dyes [15-17], and, last but not least, for glucose sensor in medical applications [18-21]. Furthermore, bimetallic nanoparticles have received more and more attention because their amazing optical, electronic, and catalytic properties, leading to various applications, as, indeed, sensors, catalysis, or SERS substrates [22-29], and so forth. Among these nanoparticles, $\mathrm{Au}_{x}-\mathrm{Ag}_{y}$ or $\mathrm{Au}_{x}-\mathrm{Pt}_{y}$ bimetallic nanoparticles have been extensively explored for different electrochemical reactions as methanol and glucose electrooxidation [30-34].

On the other hand, Gluconic acid (GA) is a high value added chemical used as intermediate in the food, pharmaceutical, and beverage industries. The only commercial/industrial method to produce GA is by glucose biochemical oxidation [35], whose main disadvantages are slow reaction rate, low space-time, and problematic enzymeproduct separation. In the past few years, heterogeneous 
TABLE 1: Composition of Au-Ag nanoparticles synthesized.

\begin{tabular}{lccccc}
\hline Sample & Composition & \% wt Au & \% wt Ag & $\mathrm{HAuCl}_{4}\left(\mathrm{~mol}^{2}\right)$ & $\mathrm{AgNO}_{3}(\mathrm{~mol})$ \\
\hline M1 & $\mathrm{Au}_{100}$ & 100 & 0 & $2.53 * 10^{-4}$ & 0 \\
M2 & $\mathrm{Au}_{90} \mathrm{Ag}_{10}$ & 90 & 10 & $2.28 * 10^{-4}$ & $4.63 * 10^{-5}$ \\
M3 & $\mathrm{Au}_{80} \mathrm{Ag}_{20}$ & 80 & 20 & $2.03 * 10^{-4}$ & $9.27 * 10^{-5}$ \\
M4 & $\mathrm{Au}_{70} \mathrm{Ag}_{30}$ & 70 & 30 & $1.77 * 10^{-4}$ & $1.39 * 10^{-4}$ \\
\hline
\end{tabular}

catalysis using $\mathrm{Pt}, \mathrm{Pd}$, or Au nanoparticles has attracted much attention [36, 37]. The selective glucose oxidation to GA has been reported using $\mathrm{Au}$ clusters as catalyst and $\mathrm{O}_{2}$ as oxidant giving a yield of $98 \%$ at mild conditions, that is, $50^{\circ} \mathrm{C}$ and atmospheric pressure. Indeed, higher costs, electrode poisoning, and hard reuse of nanocatalyst make this process far from competitive GA production [38]. Some studies have been oriented to the use of bi- and trimetallic nanoparticles to overcome the noneconomic electrochemical GA production, at least to elucidate the best nanoparticle composition for the electrooxidation of glucose. In this sense, bimetallic AuAg nanoparticles show important synergistic effects in the catalytic properties; these properties depend upon metals ratio of nanoparticle, nanoparticle synthesis, nanoparticle size, form, and crystallographic orientation [39, 40]; indeed, it has been shown that the surface morphology and particularly the size of nanoparticles can be easily controlled by experimentally adjusting the synthesis conditions [41, 42].

In our previous work, we reported that $\mathrm{Au}$ nanoparticles supported on glassy carbon presented a catalytic activity and selectivity towards glucose oxidation, depending on the particle size and on the crystallographic orientation. Results also suggest that oxidation process in these conditions is taking place with lower poisoning of the surface in the case of the Au nanoparticles than for massive gold that the process is irreversible, and perhaps there are some chemical reactions involved in the overall oxidation process [25].

The aim of this work is to evaluate the catalytic properties of $\mathrm{Au}_{x}-\mathrm{Ag}_{y} \mathrm{NPs}$ towards the glucose electrooxidation; hence, we studied mainly the Au-Ag nanoparticles voltammetric response of different $\mathrm{Au}-\mathrm{Ag}$ ratio.

\section{Experimental Section}

2.1. Preparation of $A u_{x}-A g_{y}$ Nanoparticles ( $\left.A u_{x}-A g_{y} N P s\right)$. $\mathrm{Au}_{x}-\mathrm{Ag}_{y} \mathrm{NPs}$ were prepared according to a previously published procedure [25]. The procedure has been modified in order to prepare bimetallic nanoparticles. Briefly, $30 \mathrm{~mL}$ of aqueous solutions containing the respective amount of $\mathrm{HAuCl}_{4}$ and $\mathrm{AgNO}_{3}$ to give nanoparticles $\mathrm{Au}_{100}$ (M1), $\mathrm{Au}-\mathrm{Ag}_{90 / 10}$ (M2), $\mathrm{Au}-\mathrm{Ag}_{80 / 20}$ (M3), and $\mathrm{Au}-\mathrm{Ag}_{70 / 30}$ (M4) was prepared (see Table 1) and was added to $10 \mathrm{~mL}$ of toluene (Aldrich) containing $0.34 \mathrm{mM}$ of tetraoctylammonium bromide (TOAB 98\%, Fluka) as a phase-transfer agent. Dodecanethiol (Aldrich) was incorporated to these different solutions as a stabilizing agent in an Au-Ag:thiol 2:1 ratio followed by the addition of an excess of $\mathrm{NaBH}_{4}$ as an aqueous reducing agent. The reaction was allowed to proceed under constant stirring at controlled temperature $\left(80^{\circ} \mathrm{C}\right)$, for
$3 \mathrm{~h}$. Finally, colored dispersions were obtained and purified several times in ethanol (J. T. Baker). The resulting Au-Ag nanoparticles were characterized by transmission electron microscopy (TEM), UV-Visible spectroscopy (UV-Vis), Xray diffraction spectroscopy (XRD), and cyclic voltammetry $(\mathrm{CV})$.

2.2. Preparation of Glassy Carbon Modified Electrodes. To remove the thiol stabilizing agent layer from $\mathrm{Au}_{x}-\mathrm{Ag}_{y} \mathrm{NPs}$, the NPs were mixed with Vulcan XC-72 and were heated at $300^{\circ} \mathrm{C}$ for 2 hours under air atmosphere; the temperature was controlled within $2^{\circ} \mathrm{C}$.

Then, $\mathrm{Au}_{x}-\mathrm{Ag}_{y}$ NPs-modified electrodes were prepared as follows: $1 \mu \mathrm{L}$ aliquot of thiol- $\mathrm{Au}_{x}-\mathrm{Ag}_{\gamma} \mathrm{NPs}$ in hexane and Nafion (5\% Electrochem) were mixed (1:10 ratio) and cast onto a carbon disk (CD) followed by natural evaporation at room temperature.

2.3. Characterization of Nanoparticles. Synthesized $\mathrm{Au}_{x^{-}}$ $\mathrm{Ag}_{y} \mathrm{NPs}$ were characterized using TEM, UV-Vis, XRD, and cyclic voltammetry (CV). TEM characterizations were performed on a TITAN 80-300 FEI microscope and the particle size distribution was measured from about 200 particles using the TEM images. Nanoparticles samples dissolved in hexane were cast onto a carbon-coated copper grid sample holder followed by natural evaporation at room temperature. UVVis measurements were carried out on HP spectrophotometer model 8453. XRD measurements were obtained using a Siemens D5000 diffractometer. Spectra were collected from 10 to $80^{\circ}$ at a speed of $0.002^{\circ} \cdot \mathrm{seg}^{-1}$. Cyclic voltammetric measurements were performed in BioLogic VSP Modular 5 channels Potentiostat/Galvanostat using a three-electrode conventional cell. A separated compartment and an $\mathrm{Ag} / \mathrm{AgCl}$ electrode were used as reference and a Pt wire as the counter electrode; all potentials were referred to this electrode. Glucose $0.01 \mathrm{M}$ in $\mathrm{KOH} 0.3 \mathrm{M}$ solution was used for the electrochemical characterization. The solution was purged for twenty minutes with high-purity nitrogen before taking measurements.

\section{Results and Discussion}

\subsection{Characterization of $A u_{x}-A g_{y} N P s$}

3.1.1. TEM Characterization. Figures $1(\mathrm{a})-1(\mathrm{~d})$ show TEM micrographs of the synthesized $\mathrm{Au}_{x}-\mathrm{Ag}_{y}$ nanoparticles (labeled as M1 to M4) and their particle size distribution. Synthesis of $\mathrm{Au}_{x}-\mathrm{Ag}_{y} \mathrm{NPs}$ can be easily controlled to obtain narrow particle size distribution of spherical nanoparticles 


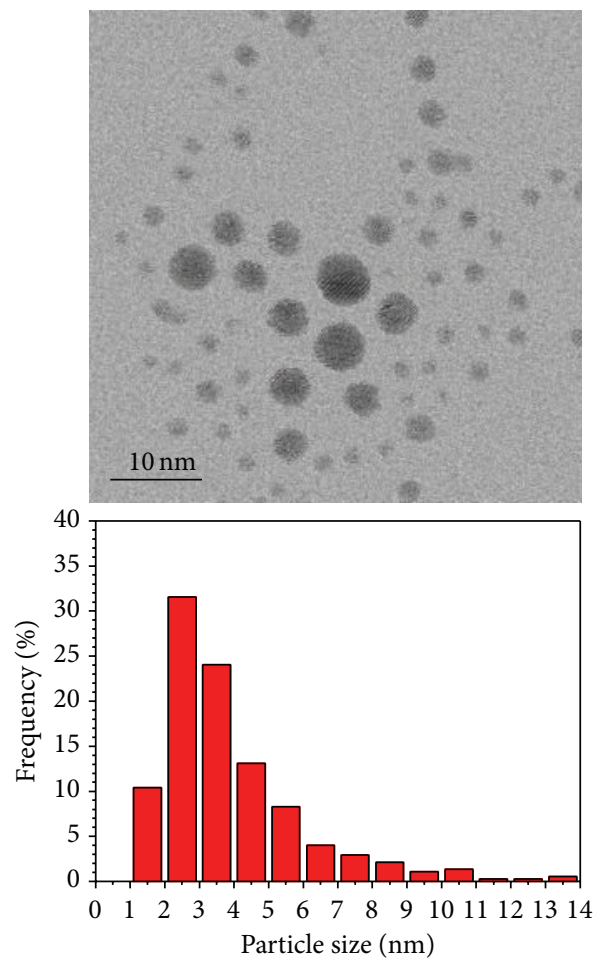

(a)

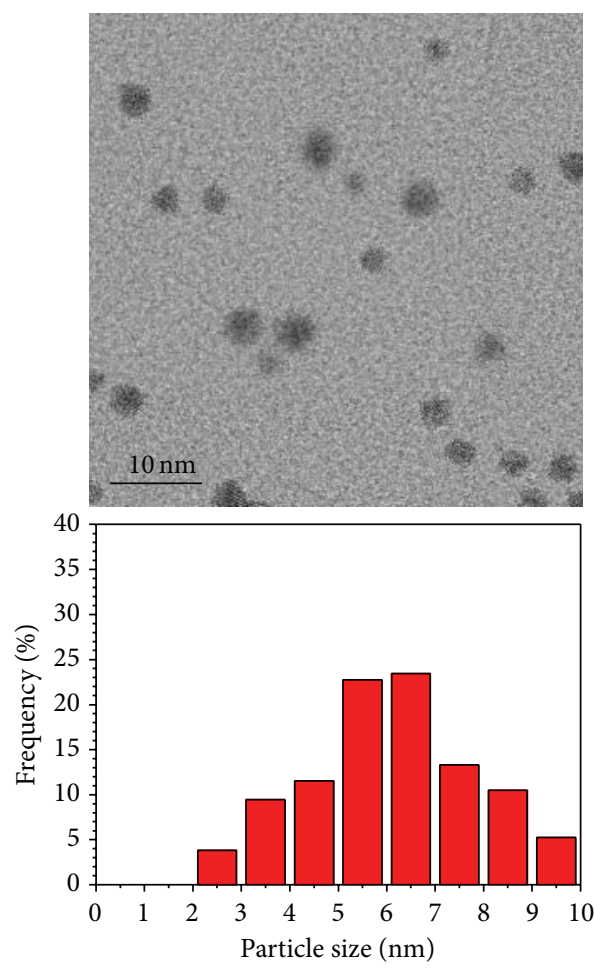

(c)

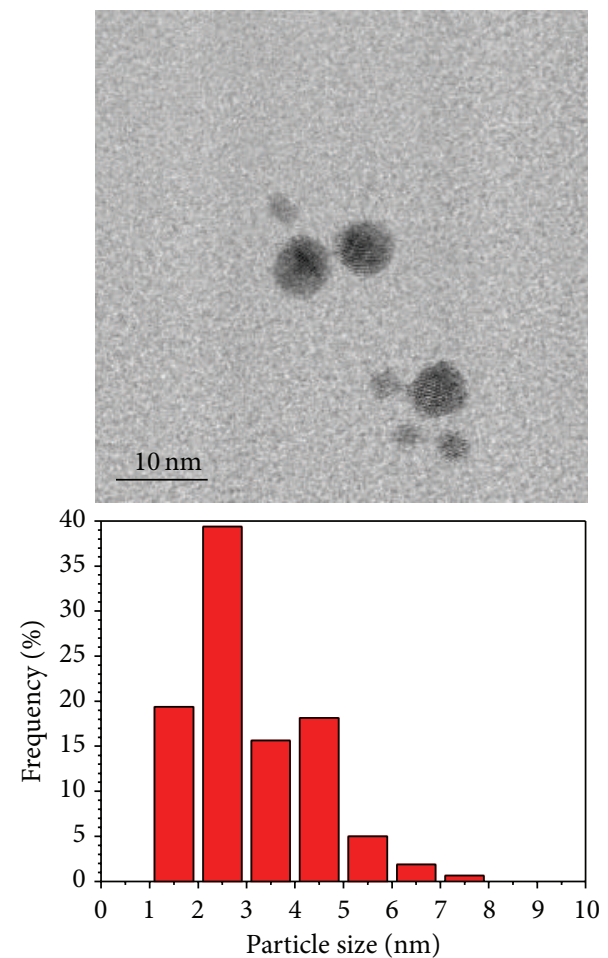

(b)

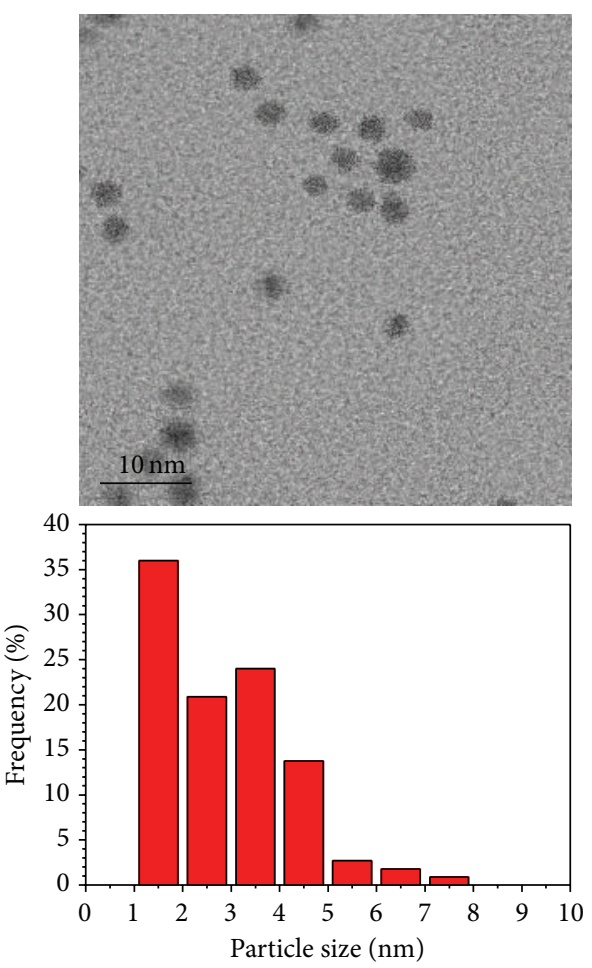

(d)

Figure 1: TEM images of thiol caped $\mathrm{Au}-\mathrm{Ag}$ bimetallic nanoparticles. (a) $\mathrm{Au}_{100} \mathrm{Ag}_{0}$, (b) $\mathrm{Au}_{90} \mathrm{Ag}_{10}$, (c) $\mathrm{Au}_{80} \mathrm{Ag}_{20}$, and (d) $\mathrm{Au}_{70} \mathrm{Ag}_{30}$. 
ranging from 1 to $7 \mathrm{~nm}$. Figures 2(a)-2(d) show the $A u_{x^{-}}$ $\mathrm{Ag}_{y} \mathrm{NPs}$ supported in Vulcan after heat treatment for thiol elimination. It can be seen that $\mathrm{Au}_{x}-\mathrm{Ag}_{y} \mathrm{NPs}$ keep their spherical form but at the same time there is an increase in size and distribution. The final size ranges from 6 to $40 \mathrm{~nm}$; in spite of the size increase, the $A u_{x}-A_{y} N P s$ are still small compared to other synthesis methods [33].

3.1.2. UV-Visible. It is well known that nanoparticles have surface plasmon (SP) resonance absorption bands in the visible region. SP resonance bands are strongly dependent on the size, shape, composition, and medium dielectric properties [43-46].

Figure 3 shows $\mathrm{UV}$-Visible spectra from $\mathrm{Au}_{x} \mathrm{Ag}_{y}$ nanoparticles dispersed in hexane. $\mathrm{Au}$ and $\mathrm{Ag}$ nanoparticles are known to have plasmon bands in the visible region located at 520 and $420 \mathrm{~nm}$, respectively. In the figure, distinct peaks are observed clearly at $530,520,512$, and $506 \mathrm{~nm}$; all these peaks are located at intermediate positions between the Au and Ag plasmon bands. The plasmon band is blue-shifted as the silver amount increases.

Two plasmon bands would be expected for a physical mixture of Au and Ag nanoparticles and the formation of an Au-Ag alloy could be deduced from the fact that the optical absorption spectrum shows only one plasmon band for all the samples [47, 48].

The formation of spherical $\mathrm{Au}_{x}-\mathrm{Ag}_{y}$ NPs was demonstrated by TEM (Figure 1). Indeed, upon heat treatment for thiol elimination, the $\mathrm{Au}_{x}-\mathrm{Ag}_{y} \mathrm{NPs}$, in spite of slight size increase, keep the spherical form as shown in Figure 2. Results are in agreement with the literature [25].

3.1.3. XRD Characterization. Figure 4 shows the XRD patterns of the different NPs synthesized. XRD analysis revealed in all the samples the presence of four representative diffraction peaks of face-centered cubic (fcc) structure that correspond to (111), (200), (220), and (311) planes. The angles of these diffraction peaks in all the samples were greater than those for pure $\mathrm{Ag}\left(38.11,44.27,64.42\right.$, and $\left.77.47^{\circ}\right)$ and lower than those for pure $\mathrm{Au}\left(38.18,44.39,64.57\right.$, and $\left.77.54^{\circ}\right)$ according to the standards for Ag [JCPDS 04-0783] and Au [JCPDS 04-0784]. These results confirm again the formation of an alloy of Au-Ag. No other impurity peak is detected in the samples.

The intensity of each signal respect to the other signals means the proportion of each orientation present in that particular nanoparticle. For nanoparticles synthesized by our method, the main factor influencing the orientation plane is the $\mathrm{Au}-\mathrm{Ag}$ : thiol ratio [25]. In this case, we used a constant $\mathrm{Au}-\mathrm{Ag}$ : thiol ratio of $2: 1$ in order to obtain a (111) : (200) plane ratio of 2.3-2.8.

3.1.4. Electrochemical Characterization. We have used cyclic voltammetry for the $\mathrm{Au}_{x}-\mathrm{Ag}_{y} \mathrm{NPs}$ electrochemical characterization. Figure 5 shows the response of both electrodes, $\mathrm{Au}$ polycrystalline (Poly-Au) (Figure 5(a)) and carbon disk $\mathrm{Au}_{100}$ nanoparticle-modified electrode (Figure 5(b)) in $0.3 \mathrm{M} \mathrm{KOH}$. We can see the typical $\mathrm{Au}$ voltammetric response, that is, the formation and reduction of Au oxides. The surface area of the $\mathrm{Au}_{100} \mathrm{NPs}$ electrode was larger than that of a Poly$\mathrm{Au}$ electrode by integrating the reduction charge of gold oxide monolayer. It indicated that there was nanostructured gold on the $\mathrm{Au}$ NPs electrode. The $\mathrm{Au}_{100} \mathrm{NPs}$ electrode exhibited the same behavior of Poly-Au electrode, having higher current densities of relative peaks compared to that of Poly-Au electrode. Poly-Au and $\mathrm{Au}_{100} \mathrm{NPs}$ electrodes exhibit the anodic peak located at $0.28 \mathrm{~V}$ corresponding to the oxidation of gold. The cathodic peak is located at $0.07 \mathrm{~V}$ for $\mathrm{Au}_{100} \mathrm{NPs}$ and $0.1 \mathrm{~V}$ for Poly-Au corresponding to the subsequent reduction of the gold oxides. Nevertheless, there was a weak cathodic peak located at $-0.2 \mathrm{~V}$ for $\mathrm{Au}_{100} \mathrm{NPs}$ and $-0.18 \mathrm{~V}$ for Poly-Au attributed to desorption of hydroxide anions.

As the content of $\mathrm{Ag}$ in nanoparticles increases $\left(\mathrm{Au}_{80} \mathrm{Ag}_{20}\right.$ and $\mathrm{Au}_{70} \mathrm{Ag}_{30}$, Figures 5(c) and 5(d)), the voltammogram changes to take the form of that of $\mathrm{Ag}$ nanoparticles in alkaline media (Figures 5(e) and 6(f)) [49]. The cyclic voltammograms of the silver disk electrode or silver nanoparticlemodified electrode in alkaline media show three anodic peaks $\left(\mathrm{Ox}_{1}, \mathrm{Ox}_{2}\right.$, and $\left.\mathrm{Ox}_{3}\right)$ appearing at $0.25,0.33$, and $0.65 \mathrm{~V}$, respectively (Figures 5(e) and 6(f)). During a reverse scan, two cathodic peaks $\left(\mathrm{R}_{1}\right.$ and $\left.\mathrm{R}_{2}\right)$ appeared at 0.38 and $0.06 \mathrm{~V}$, respectively, as reported in previous studies [49]. The first anodic peak $\left(\mathrm{Ox}_{1}\right)$ is due to the electroformation of the monolayer of $\mathrm{Ag}_{2} \mathrm{O}$. The second anodic peak $\left(\mathrm{Ox}_{2}\right)$ is due to the formation of the multilayer of $\mathrm{Ag}_{2} \mathrm{O}$. The third peak $\left(\mathrm{Ox}_{3}\right)$ is due to the oxidation of $\mathrm{Ag}_{2} \mathrm{O}$ to $\mathrm{AgO}$ or direct oxidation of $\mathrm{Ag}$ to $\mathrm{AgO}$.

The cathodic current peak $\mathrm{R}_{1}$ is due to the reduction of $\mathrm{AgO}$ to $\mathrm{Ag}_{2} \mathrm{O}$, and $\mathrm{R}_{2}$ corresponds to the reduction of $\mathrm{Ag}_{2} \mathrm{O}$ to Ag. A small anodic peak $\left(\mathrm{Ox}_{4}\right)$ at $0.63 \mathrm{~V}$ appears during the cathodic scan, but it was dependent on the scan rate and occurred only when the scan rate is faster than $50 \mathrm{mV} / \mathrm{s}$. Stonehart has suggested that peak $\mathrm{Ox}_{4}$ is associated with autocatalytic oxidation process to convert $\mathrm{Ag}_{2} \mathrm{O}$ to $\mathrm{AgO}$ [50]. When the nuclei of $\mathrm{AgO}$ formed at the $\mathrm{Ag}_{2} \mathrm{O}$ surface during the anodic scan, further formation of AgO became easy and occurred at a lower potential than the initial formation of AgO nuclei. Therefore, during the cathodic scan, further formation of $\mathrm{AgO}$ resulted in the appearance of a small anodic peak.

It can be seen in Figure 5(c) $\left(\mathrm{Au}_{80} \mathrm{Ag}_{20}\right)$ that the anodic scan shows three peaks probably due to the oxidation of gold $\left(\mathrm{Ox}_{1}\right)$, the electroformation of the monolayer of $\mathrm{Ag}_{2} \mathrm{O}$ $\left(\mathrm{Ox}_{2}\right)$, and the oxidation of $\mathrm{Ag}_{2} \mathrm{O}$ to $\mathrm{AgO}\left(\mathrm{Ox}_{3}\right)$. The cathodic scan shows also three peaks probably corresponding to the reduction of $\mathrm{AgO}$ to a multilayer of $\mathrm{Ag}_{2} \mathrm{O}\left(\mathrm{R}_{1}\right)$, the reduction of $\mathrm{Ag}_{2} \mathrm{O}$ to $\mathrm{Ag}\left(\mathrm{R}_{2}\right)$, and the reduction of Au oxides $\left(\mathrm{R}_{3}\right)$.

As a consequence of the increase in Ag content, the anodic scan of $\mathrm{Au}_{70} \mathrm{Ag}_{30} \mathrm{NPs}$ shows two peaks. The first one $\left(\mathrm{Ox}_{1}\right)$ is clearly due to the simultaneous formation of $\mathrm{Au}$ oxides and the formation of the $\mathrm{Ag}_{2} \mathrm{O}$ monolayer because practically these two processes take place at the same potential resulting in one peak; the second anodic peak $\left(\mathrm{Ox}_{2}\right)$ is due to the oxidation of $\mathrm{Ag}_{2} \mathrm{O}$ to $\mathrm{AgO}$. The cathodic scan shows four peaks: $R_{1}$ is due to the reduction of $\mathrm{AgO}$ to a multilayer of $\mathrm{Ag}_{2} \mathrm{O}, \mathrm{R}_{2}$ is due to the reduction of $\mathrm{Ag}_{2} \mathrm{O}$ to $\mathrm{Ag}$, and 


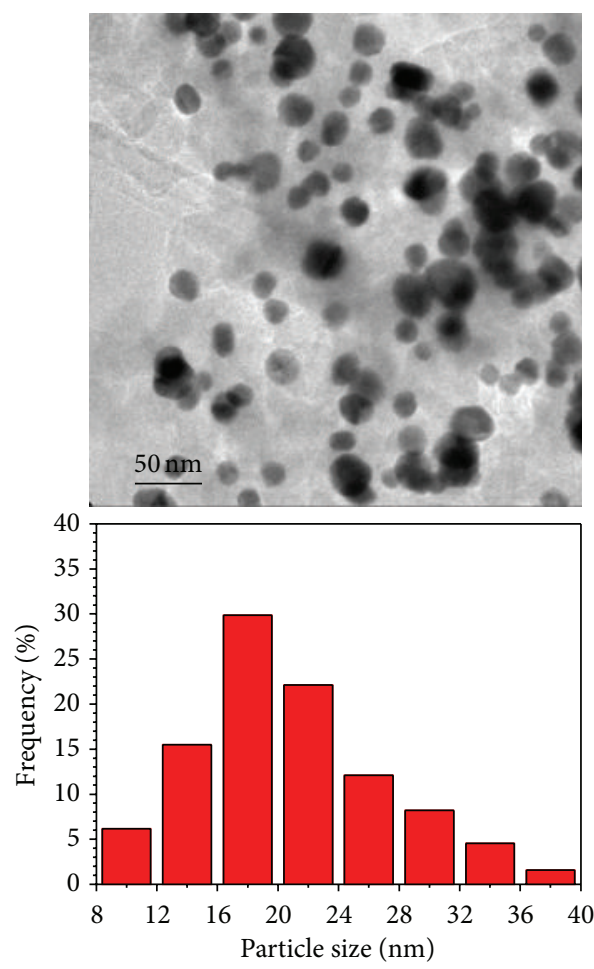

(a)

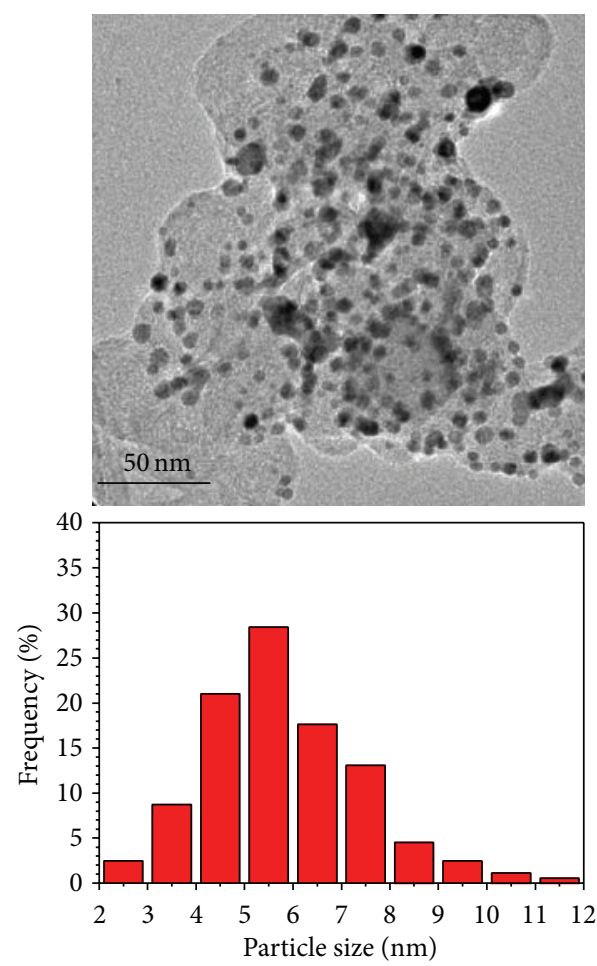

(c)

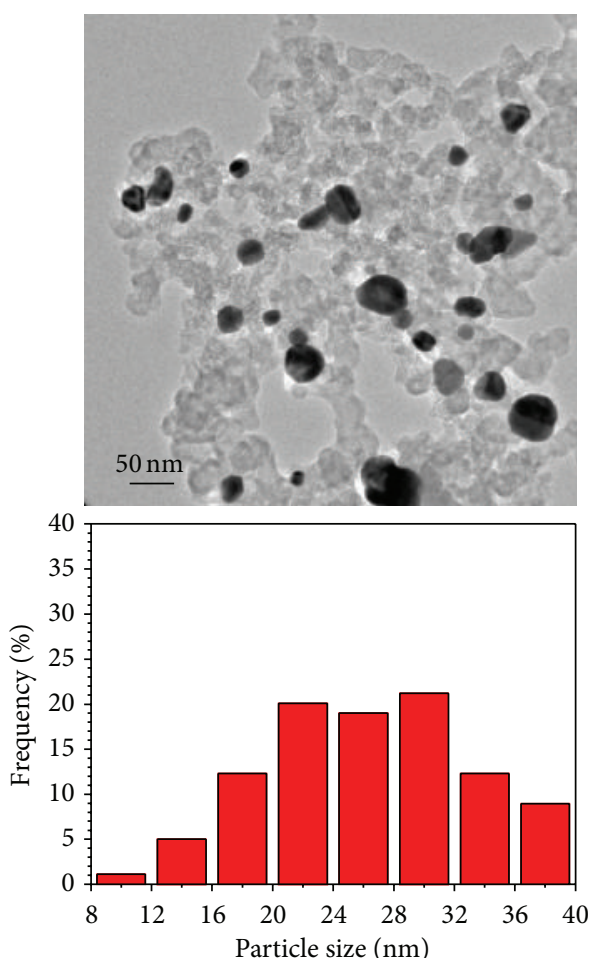

(b)

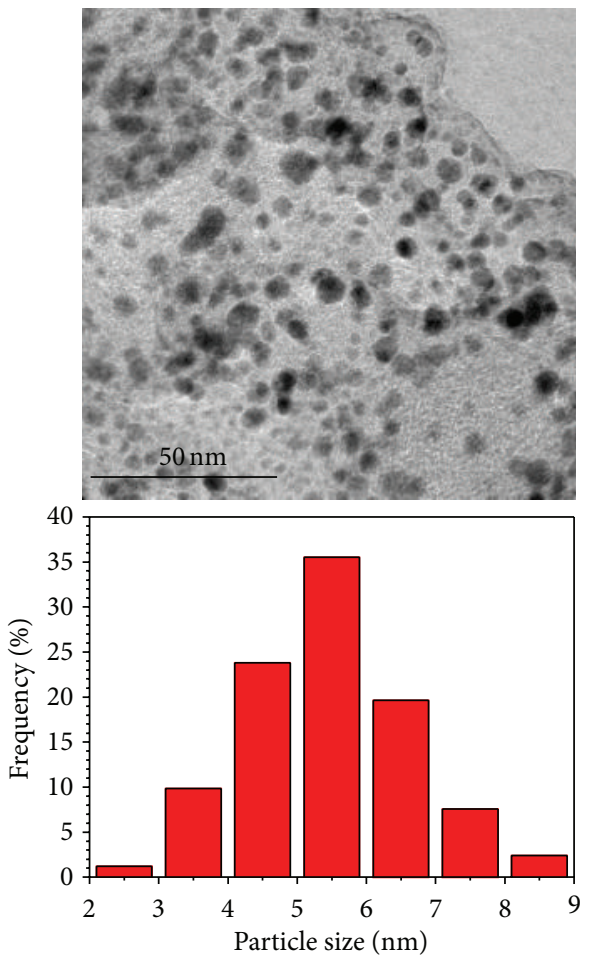

(d)

FIGURE 2: TEM images of Au-Ag bimetallic nanoparticles supported in Vulcan after heat treatment for thiol elimination. (a) $\mathrm{Au}_{100} \mathrm{Ag}_{0}$, (b) $\mathrm{Au}_{90} \mathrm{Ag}_{10}$, (c) $\mathrm{Au}_{80} \mathrm{Ag}_{20}$, and (d) $\mathrm{Au}_{70} \mathrm{Ag}_{30}$. 


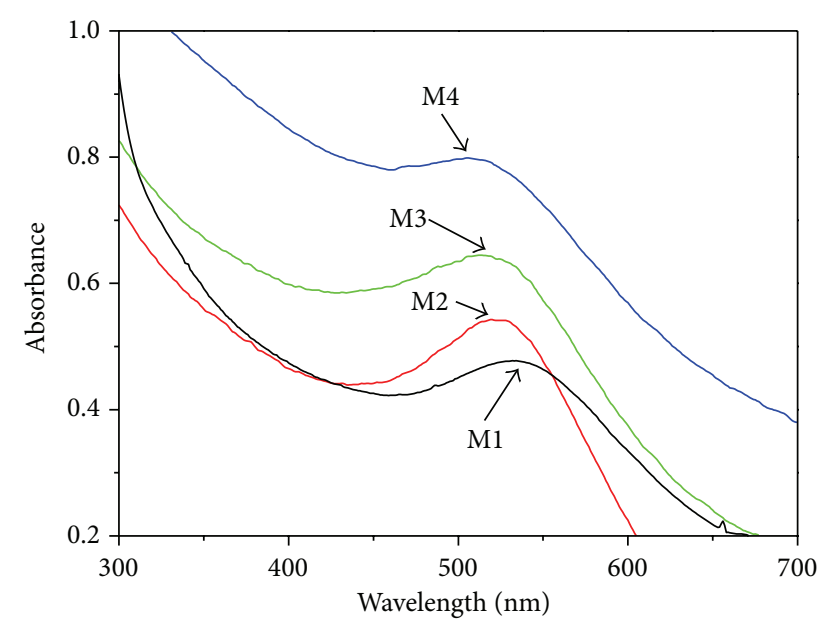

FIgURE 3: UV-vis spectra of bimetallic nanoparticles at different $\mathrm{Au}-\mathrm{Ag}$ molar compositions. (M1) $\mathrm{Au}_{100} \mathrm{Ag}_{0}$, (M2) $\mathrm{Au}_{90} \mathrm{Ag}_{10}$, (M3) $\mathrm{Au}_{80} \mathrm{Ag}_{20}$, and (M4) $\mathrm{Au}_{70} \mathrm{Ag}_{30}$.

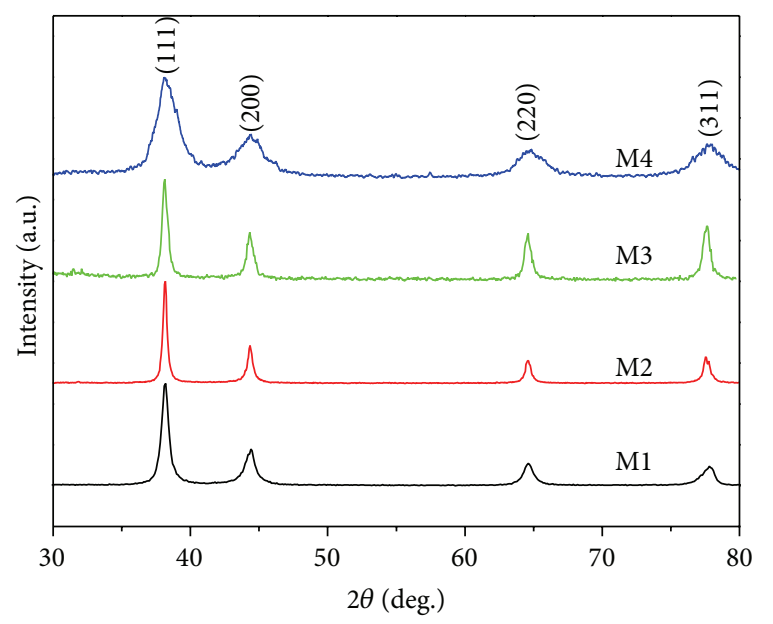

FIGURE 4: XRD patterns of different nanoparticles. (M1) $\mathrm{Au}_{100} \mathrm{Ag}_{0}$, (M2) $\mathrm{Au}_{90} \mathrm{Ag}_{10}$, (M3) $\mathrm{Au}_{80} \mathrm{Ag}_{20}$, and (M4) $\mathrm{Au}_{70} \mathrm{Ag}_{30}$.

peaks $R_{3}$ and $R_{4}$ are due to the reduction of the gold oxides and the desorption of hydroxide anions. These results are in agreement with others works $[49,51]$.

\subsubsection{Electrochemical Oxidation of Glucose on AuNPs and} $A u$-AgNPs. Figures 6(a)-6(e) compares the voltammograms obtained for the electrochemical oxidation of $10 \mathrm{mM}$ glucose at the Poly-Au electrode and the $\mathrm{Au}_{x}-\mathrm{Ag}_{y} \mathrm{NPs}$ electrodes in $0.3 \mathrm{M} \mathrm{KOH}$ solution. The Poly-Au and the $\mathrm{Au}_{x}-\mathrm{Ag}_{y} \mathrm{NPs}$ electrodes demonstrated a typical voltammetric response for glucose. Interestingly, the current density of oxidation of glucose on the $\mathrm{Au}_{x}-\mathrm{Ag}_{y} \mathrm{NPs}$ electrodes was higher than that on Poly-Au electrode; it could be attributed to the high surface area of $\mathrm{Au}_{x}-\mathrm{Ag}_{y} \mathrm{NPs}$. However, the only $\mathrm{Au}_{x}-$ $\mathrm{Ag}_{y} \mathrm{NPs}$ electrode that did not show better performance is the M4 electrode $\left(\mathrm{Au}_{70}-\mathrm{Ag}_{30}\right)$; hence, we discard it for further experiments and analysis.
TABLE 2: Oxidation peak and current density as a function of $\mathrm{Ag}$ content.

\begin{tabular}{lcc}
\hline Sample & $\begin{array}{c}\text { Potential, E/V versus } \\
\mathrm{Ag} / \mathrm{AgCl} / \mathrm{KCl} \text { sat'd }\end{array}$ & $\begin{array}{c}\text { Current density } \\
\left(\mathrm{mAcm}^{-2}\right) @ 0.49 \mathrm{~V} \\
\text { versus } \mathrm{Ag} / \mathrm{AgCl} / \mathrm{KCl} \\
\text { sat'd }\end{array}$ \\
\hline Poly-Au & $-0.52 \pm 0.01$ & $1.0 \pm 0.1$ \\
$\mathrm{M} 1\left(\mathrm{Au}_{100}-\mathrm{Ag}_{0}\right)$ & $-0.39 \pm 0.03$ & $1.2 \pm 0.1$ \\
$\mathrm{M} 2\left(\mathrm{Au}_{90}-\mathrm{Ag}_{10}\right)$ & $-0.41 \pm 0.04$ & $0.82 \pm 0.1$ \\
$\mathrm{M} 3\left(\mathrm{Au}_{80}-\mathrm{Ag}_{20}\right)$ & $-0.49 \pm 0.04$ & $1.9 \pm 0.3$ \\
$\mathrm{M} 4\left(\mathrm{Au}_{70}-\mathrm{Ag}_{30}\right)$ & $-0.54 \pm 0.04$ & $0.5 \pm 0.1$ \\
\hline
\end{tabular}

There is also a shift of the glucose potential oxidation on the $\mathrm{Au}_{x}-\mathrm{Ag}_{y} \mathrm{NPs} \mathrm{M1}, \mathrm{M} 2$, and M3 electrodes with respect to the Poly-Au electrode (see Table 2); the shift is to less-negative potentials and reveals that the $\mathrm{Au}_{x}-\mathrm{Ag}_{y} \mathrm{NPs}$ electrodes could catalyze the oxidation of glucose. Indeed, we show in Table 2, for comparison purposes, the current density under the same potential for the electrode tested. These results are similar to that of Qiaofan's work on glucose oxidation in an alkaline electrolyte obtained at bimetallic $\mathrm{Au}-\mathrm{Ag} / \mathrm{RGO} / \mathrm{GC}$ (bimetallic Au-Ag/reduced grapheme oxide/glassy carbon) nanoparticles modified electrode [51].

The CV curves of the $\mathrm{Au}_{x}-\mathrm{Ag}_{y} \mathrm{NPs}$ electrode presented a typical two-step oxidation process and three obvious oxidation peaks in the positive scan were observed. As the mechanism for the electrocatalytic oxidation of glucose at $\mathrm{Au}_{x}-\mathrm{Ag}_{y} \mathrm{NPs}$ electrodes is a multistep one, the first step mediated the chemisorptions of hydroxide anions onto the electrode surface, leading to the formation of hydrous goldsilver oxide $\left(\mathrm{Au}_{x}-\mathrm{Ag}_{y} \mathrm{OH}_{\mathrm{ads}}\right)$ which was believed to be the catalytic component of $\mathrm{Au}_{x}-\mathrm{Ag}_{y} \mathrm{NPs}$ electrodes [52].

The glucose oxidation highly depends on the quantity of $\mathrm{Au}_{x}-\mathrm{Ag}_{y} \mathrm{OH}_{\mathrm{ads}}$ and the premonolayer oxidation was enhanced at $\mathrm{Au}_{x}-\mathrm{Ag}_{y} \mathrm{NPs}$ surface. The first peak, $\mathrm{Ox}_{1}$, located between -0.54 and $-0.39 \mathrm{~V}$ could be attributed to the electrosorption of glucose to form adsorbed intermediate gluconolactone, releasing one proton per glucose molecule. At around these potentials, there could be a very limited number of $\mathrm{Au}_{x}-\mathrm{Ag}_{y} \mathrm{OH}_{\mathrm{ads}}$ sites on the $\mathrm{Au}_{x}-\mathrm{Ag}_{y} \mathrm{NPs}$ surfaces due to the reductive nature of the electrodes potential. Glucose molecules interacted with the $\mathrm{Au}_{x}-\mathrm{Ag}_{y} \mathrm{OH}_{\text {ads }}$ sites to give rise to the intermediate, gluconolactone $[53,54]$. Nevertheless, the accumulation of gluconolactone blocks the active sites of the $\mathrm{Au}_{x}-\mathrm{Ag}_{y} \mathrm{NPs}$ electrode surface inhibiting the direct oxidation of glucose, leading to the decrease of current density. The second oxidation peak $\mathrm{Ox}_{2}$ appeared at a more positive potential located between 0.18 and $0.26 \mathrm{~V}$ depending on the $\mathrm{Ag}$ content in the electrode. When the potential reaches those values, the population of $\mathrm{Au}_{x}-\mathrm{Ag}_{y} \mathrm{OH}_{\mathrm{ads}}$ sites on the $\mathrm{Au}_{x^{-}}$ $\mathrm{Ag}_{\mathrm{y}} \mathrm{NPs}$ electrode increased; hence, catalytic oxidation of the intermediates takes place. A further positive increase in the potential to around $0.6 \mathrm{~V}$ gives rise to the formation of goldsilver oxides on the surface of $\mathrm{Au}_{x}-\mathrm{Ag}_{y} \mathrm{NPs}$. The formation of Au-Ag oxides results in a decrease of the number of the $\mathrm{Au}_{x}-\mathrm{Ag}_{y} \mathrm{OH}_{\mathrm{ads}}$ sites on the surface $\mathrm{Au}_{x}-\mathrm{Ag}_{y} \mathrm{NPs}$ and impedes the electrocatalytic oxidation of glucose and by-products. The 


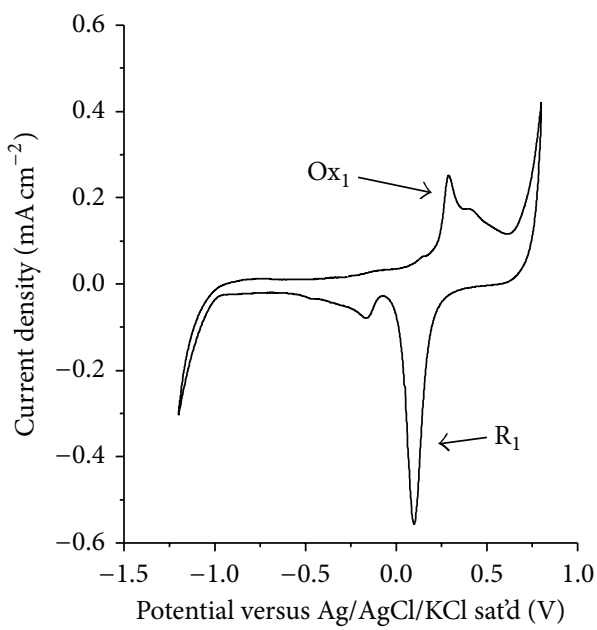

(a)

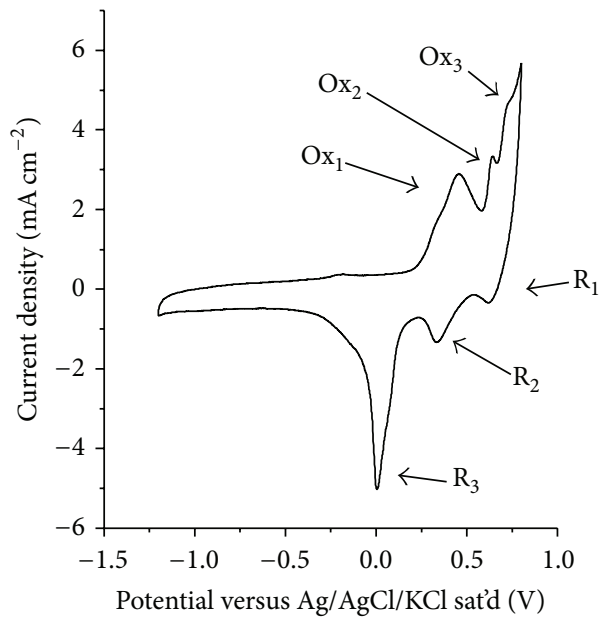

(c)

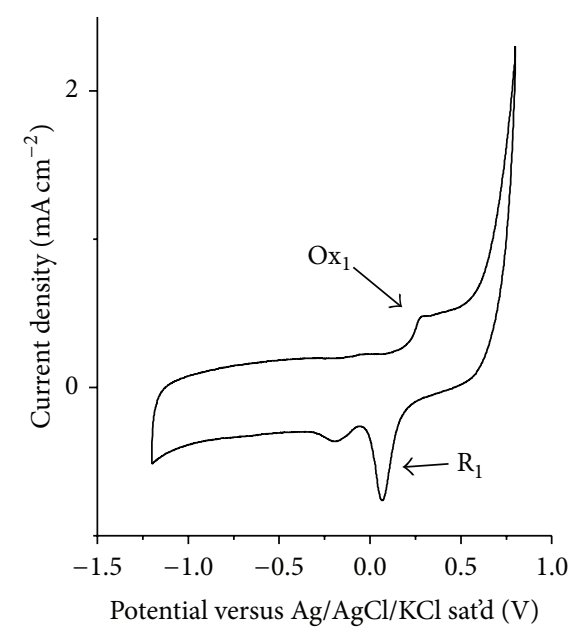

(b)

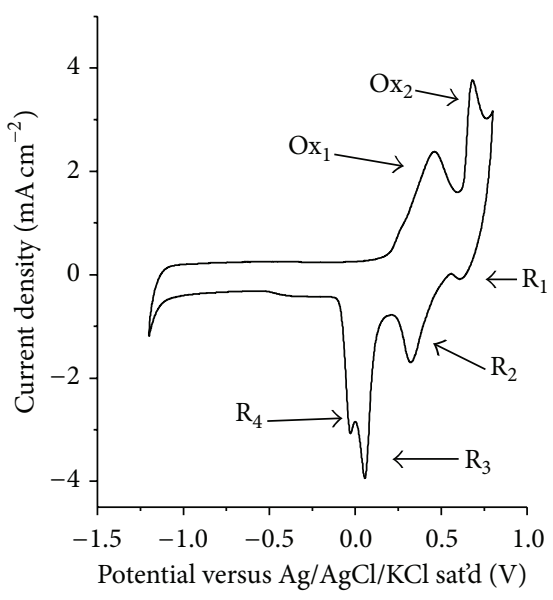

(d)

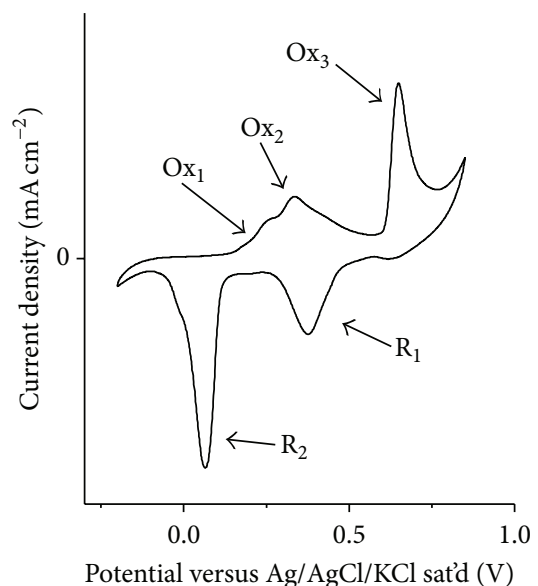

(e)

Figure 5: CV curves in $0.3 \mathrm{M} \mathrm{KOH}$ solution for (a) solid Au electrode, (b) $\mathrm{Au}_{100}$, (c) $\mathrm{Au}_{80} \mathrm{Ag}_{20}$, (d) $\mathrm{Au}_{70} \mathrm{Ag}_{30}$, and (e) $\mathrm{Au}_{0} \mathrm{Ag}_{100}$. $\mathrm{Scan}$ rate, $50 \mathrm{mV} \mathrm{s}^{-1}$. Scan direction $\rightarrow$. 


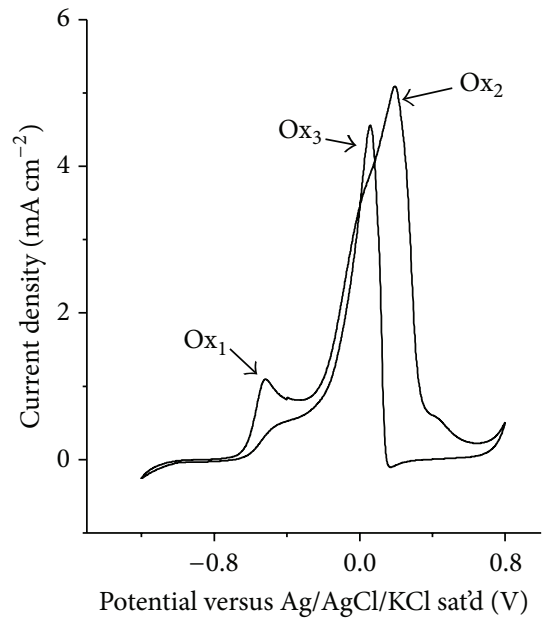

(a)

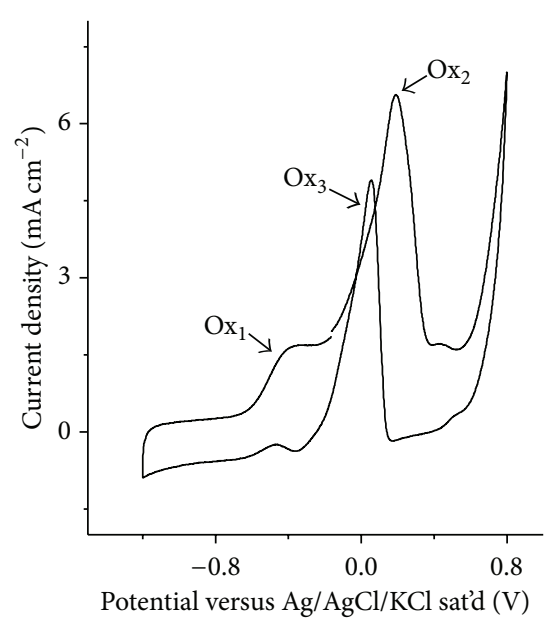

(b)

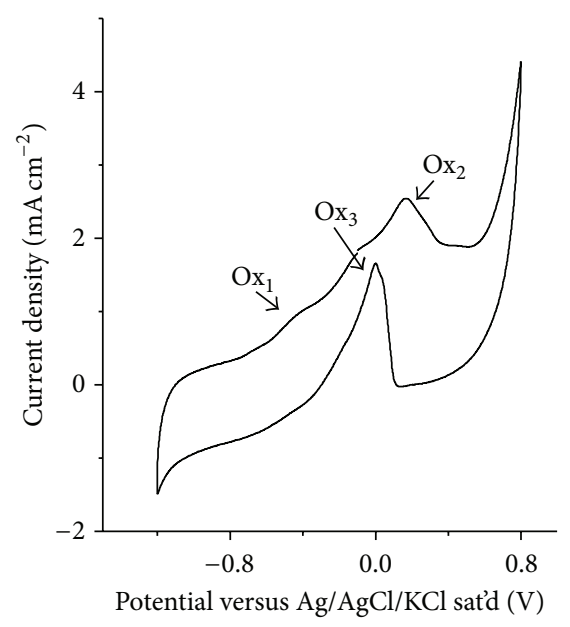

(c)

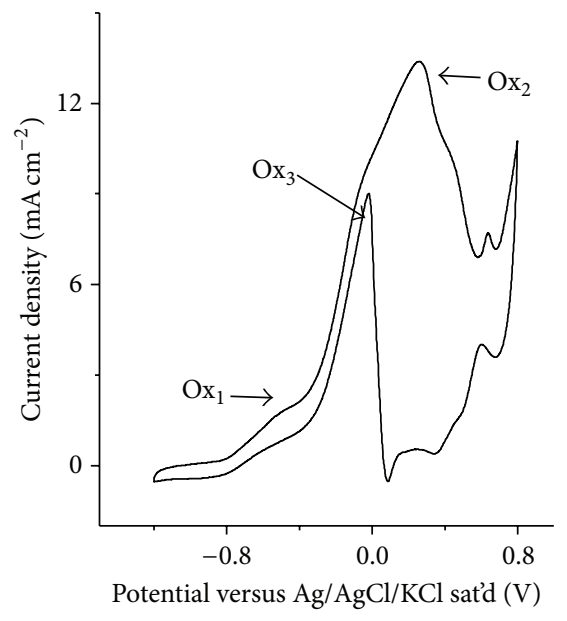

(d)

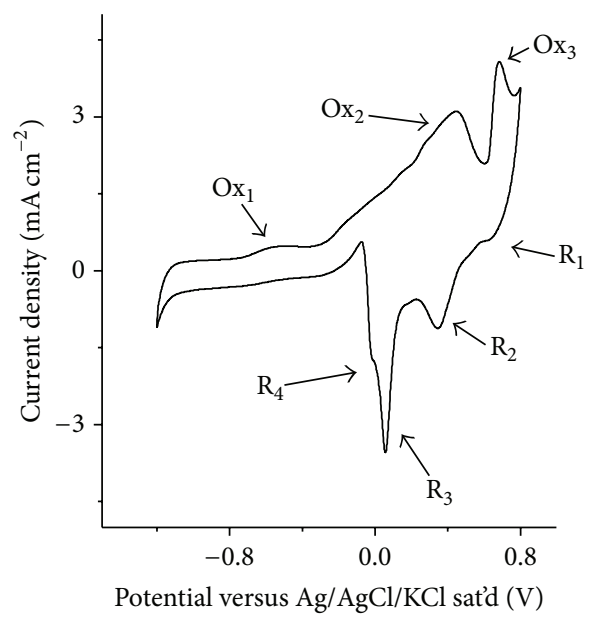

(e)

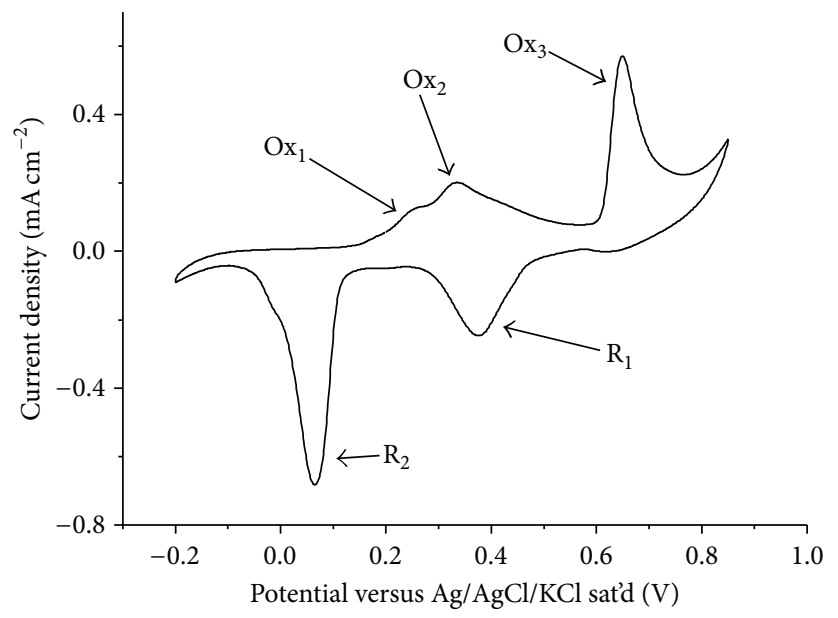

(f)

Figure 6: CV curves in $0.3 \mathrm{M} \mathrm{KOH}+10 \mathrm{mM}$ glucose solution for (a) solid Au electrode, (b) $\mathrm{Au}_{100} \mathrm{NP}$ electrode, (c) $\mathrm{Au}_{90} \mathrm{Ag}_{10}$, (d) $\mathrm{Au}_{80} \mathrm{Ag}_{20}$, (e) $\mathrm{Au}_{70} \mathrm{Ag}_{30}$, and (f) $\mathrm{Au}_{0} \mathrm{Ag}_{100}$. Scan rate, $50 \mathrm{mVs}^{-1}$. Scan direction $\rightarrow$. 

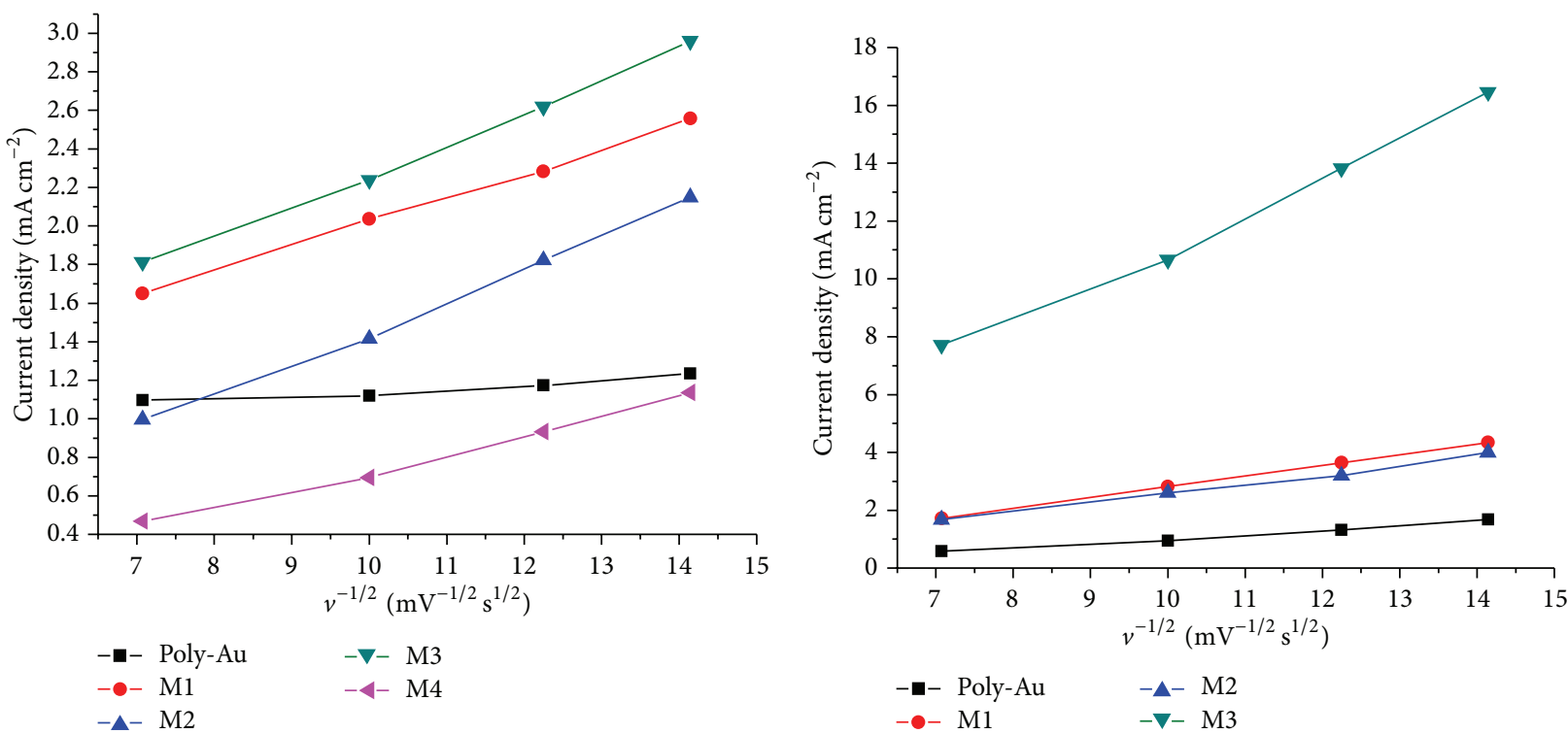

(a)

(b)

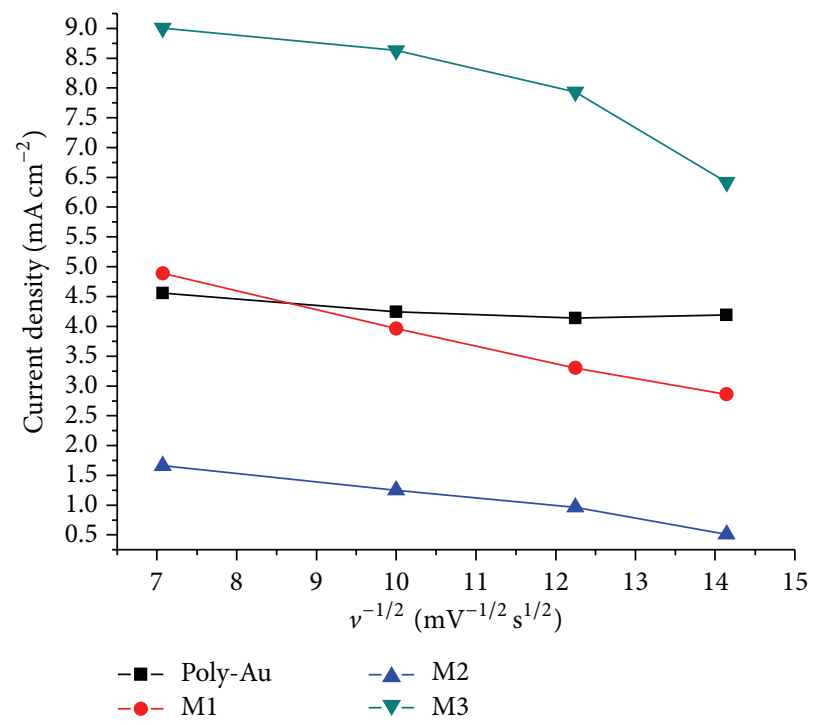

(c)

Figure 7: Plots of current density versus $\mathrm{V}^{-1 / 2}$ (a) first oxidation scan peak, (b) second oxidation scan peak, and (c) oxidation cathodic peak.

current density, then, decreases dramatically at more positive values than $0.60 \mathrm{~V}$, due to formation of gold and silver oxides. In the negative potential scan, the reduction of the surface gold and silver oxides would occur at the potential more negative than $0.16 \mathrm{~V}$. Then, enough surface active sites would be available for the direct oxidation of glucose, resulting in a sharp increase in anodic current showing a peak $\left(\mathrm{Ox}_{3}\right)$, located between 0.001 and $0.15 \mathrm{~V}$, depending on the Ag content in the electrode. Tang's group had reported a similar result; that is, there is a sharp increase in anodic current with a peak at $0.1 \mathrm{~V}$ [53]. The surface structure of a gold electrode influenced the electrooxidation of glucose via the influence on the adsorption of $\mathrm{OH}^{-}$anions and gold oxide surface monolayer formation [55]. The as-prepared $\mathrm{Au}_{x}-\mathrm{Ag}_{y} \mathrm{NPs}$ electrode exhibited better performance on electrocatalytic oxidation toward glucose than a Poly-Au electrode.

To evaluate the kinetics of the glucose oxidation on the $\mathrm{Au}_{x}-\mathrm{Ag}_{y} \mathrm{NPs}$, the CVs of the electrodes in a $0.3 \mathrm{M} \mathrm{KOH}$ solution containing $10 \mathrm{mM}$ glucose at different scan rates were recorded (figure not shown). The peak $\mathrm{Ox}_{1}$ in the positive scan, located between -0.54 and $-0.39 \mathrm{~V}$, corresponds to the direct oxidation of glucose and the current density is proportional to the square root of scan rate for all the electrodes used (Poly-Au, M1, M2, M3, and M4, Figure $7(\mathrm{a})$ ); this fact suggests a linear diffusion-controlled process. Indeed, it is in agreement with the proposed mechanism for peak $\mathrm{Ox}_{1}$, in which sufficient active sites on the hydroxyl coated gold surface allowed direct oxidation of 
glucose to generate gluconolactone $[25,56]$. We can see that the order from better to worst with respect to the glucose oxidation is M3 > M1 > M2 > Poly-Au > M4. As expected, the current density of all electrodes increases as scan rate rises but that of Poly-Au remains practically unchanged. Furthermore, the slope of $\mathrm{Au}_{x}-\mathrm{Ag}_{y}$ NPs increases depending on the $\mathrm{Ag}$ content in the NPs. The $\mathrm{Au}_{80}-\mathrm{Ag}_{20}$ electrode has the highest slope, that is, the highest glucose oxidation rate.

In Figure 7(b), we can see the plot of current density versus square root of scan rate corresponding to the further oxidation of gluconolactone located between 0.18 and $0.26 \mathrm{~V}$ $\left(\mathrm{Ox}_{2}\right)$ on the same electrodes except that of M4. Figure 7(b) suggests again that the oxidation of gluconolactone is also a diffusion-controlled process. The order from better to worst is M3 > M1 > Poly-Au > M2. This time, the slope of Poly-Au increases as expected; we are working on the matter.

Finally, Figure $7(\mathrm{c})$ shows the plot of current density versus square root of scan rate for the oxidation peak $\mathrm{Ox}_{3}$. Interestingly, as could be seen, peak $\mathrm{Ox}_{3}$ corresponds to the direct oxidation of glucose in cathodic scan and is also linear versus scan rates. Indeed, this is a typical adsorptioncontrolled process corresponding to a fast electron-transfer behavior. In the negative potential scan, the reduction of the gold surface oxides provides enough surface active sites for the direct oxidation of glucose; they could account for the appearance of peak $\mathrm{Ox}_{3}$. The order from better to worst is $\mathrm{M} 3$ $>$ Poly-Au > M1 > M2. This time, the slope of Poly-Au remains again unchanged.

None of the straight lines of plots in Figures 7(a), 7(b), and $7(\mathrm{c})$ go through origin indicating a previous chemical step in the oxidation process; as noted above, this step is probably due to the chemisorption of hydroxide anions onto the gold and silver surface, leading to the formation of hydrous oxides $\left(\mathrm{Au}_{x}-\mathrm{Ag}_{y} \mathrm{OH}_{\text {ads }}\right)$, which are believed to be the catalytic component of $\mathrm{Au}_{x}-\mathrm{Ag}_{y} \mathrm{NPs}$ electrodes, particularly $\mathrm{Au}_{80}-\mathrm{Ag}_{20} \mathrm{NPs}$ electrode.

\section{Conclusion}

The nanoparticles applications, for instance, glucose oxidation, critically depend on their specific catalytic activity; unfortunately, it is still poorly understood [57]. Experimental evidence that can be found in literature points towards several variables affecting it, that is, nanoparticle size [57], nanoparticle crystal orientation [56], and composition of nanoparticle [51]. It is admitted that the glucose oxidation depends on the presence of what is known as monolayer or premonolayer of $\mathrm{AuOH}_{\mathrm{ads}}$ or $\mathrm{AgOH}_{\mathrm{ads}}$ [48]; at higher potential, the formation of $\mathrm{Au}$ and $\mathrm{Ag}$ oxides impedes the glucose oxidation. Nevertheless, Mikhlin et al. [57] found that the formation of AgO proceeded readily at the "primary" oxide for nanoparticles of about $12 \mathrm{~nm}$ but was retarded at the smaller ones. These findings are in agreement with our previous work where we have found a maximum in the catalytic activity for Au nanoparticles of about $6 \mathrm{~nm}$ and could explain the present findings; that is, smaller nanoparticles have the highest catalytic activity towards glucose oxidation.
Regarding nanoparticle composition, the experimental evidence strongly suggests that the best composition is around $80 \% \mathrm{Au}$ and $20 \% \mathrm{Ag}$.

Indeed, we have performed the present study for a (111) : (200) plane ratio of 2.3-2.8. Studies to optimizing the NPs size, Au-Ag ratio, and crystallographic orientation are underway.

\section{Conflict of Interests}

The authors declare that there is no conflict of interests regarding the publication of this paper.

\section{Acknowledgments}

Authors are grateful for financial support from CONACYT Project CB-2012-01 183463 and scholarship of Nancy Gabriela García Morales. Authors would also thank Azucena OsornioVilla, Carlos Fernando Bautista Alegría, and Erick Montenegro Hernández for helping in preparing this paper.

\section{References}

[1] Y. B. Vassilyev, O. A. Khazova, and N. N. Nikolaeva, "Kinetics and mechanism of glucose electrooxidation on different electrode-catalysts. Part II. Effect of the nature of the electrode and the electrooxidation mechanism," Journal of Electroanalytical Chemistry, vol. 196, no. 1, pp. 127-144, 1985.

[2] L. A. Larew and D. C. Johnson, "Concentration dependence of the mechanism of glucose oxidation at gold electrodes in alkaline media," Journal of Electroanalytical Chemistry and Interfacial Electrochemistry, vol. 262, no. 1-2, pp. 167-182, 1989.

[3] R. R. Adzic, M. W. Hsiao, and E. B. Yeager, "Electrochemical oxidation of glucose on single crystal gold surfaces," Journal of Electroanalytical Chemistry and Interfacial Electrochemistry, vol. 260, no. 2, pp. 475-485, 1989.

[4] K. B. Kokoh, J.-M. Léger, B. Beden, H. Huser, and C. Lamy, “'On line' chromatographic analysis of the products resulting from the electrocatalytic oxidation of d-glucose on pure and adatoms modified Pt and Au electrodes-Part II. Alkaline medium," Electrochimica Acta, vol. 37, no. 11, pp. 1909-1918, 1992.

[5] M. W. Hsiao, R. R. Adžić, and E. B. Yeager, "Electrochemical oxidation of glucose on single crystal and polycrystalline gold surfaces in phosphate buffer," Journal of the Electrochemical Society, vol. 143, no. 3, pp. 759-767, 1996.

[6] S. B. Aoun, Z. Dursun, T. Koga, G. S. Bang, T. Sotomura, and I. Taniguchi, "Effect of metal ad-layers on $\mathrm{Au}(111)$ electrodes on electrocatalytic oxidation of glucose in an alkaline solution," Journal of Electroanalytical Chemistry, vol. 567, no. 2, pp. 175183, 2004.

[7] S. Ben Aoun, G. S. Bang, T. Koga, Y. Nonaka, T. Sotomura, and I. Taniguchi, "Electrocatalytic oxidation of sugars on silver-UPD single crystal gold electrodes in alkaline solutions," Electrochemistry Communications, vol. 5, no. 4, pp. 317-320, 2003.

[8] M. Tominaga, T. Shimazoe, M. Nagashima, and I. Taniguchi, "Electrocatalytic oxidation of glucose at gold nanoparticlemodified carbon electrodes in alkaline and neutral solutions," Electrochemistry Communications, vol. 7, no. 2, pp. 189-193, 2005. 
[9] M. Tominaga, T. Shimazoe, M. Nagashima et al., "Electrocatalytic oxidation of glucose at gold-silver alloy, silver and gold nanoparticles in an alkaline solution," Journal of Electroanalytical Chemistry, vol. 590, no. 1, pp. 37-46, 2006.

[10] M. Tominaga, M. Nagashima, K. Nishiyama, and I. Taniguchi, "Surface poisoning during electrocatalytic monosaccharide oxidation reactions at gold electrodes in alkaline medium," Electrochemistry Communications, vol. 9, no. 8, pp. 1892-1898, 2007.

[11] M. Tominaga, T. Shimazoe, M. Nagashima, and I. Taniguchi, "Electrocatalytic oxidation of glucose at carbon electrodes modified with gold and gold-platinum alloy nanoparticles in an alkaline solution," Chemistry Letters, vol. 34, no. 2, pp. 202-203, 2005.

[12] M. Guerra-Balcázar, D. Morales-Acosta, F. Castañeda, J. Ledesma-García, and L. G. Arriaga, "Synthesis of $\mathrm{Au} / \mathrm{C}$ and $\mathrm{Au} / \mathrm{Pani}$ for anode electrodes in glucose microfluidic fuel cell," Electrochemistry Communications, vol. 12, no. 6, pp. 864-867, 2010.

[13] F. M. Cuevas-Muñiz, M. Guerra-Balcázar, F. Castaneda, J. Ledesma-García, and L. G. Arriaga, "Performance of Au and AuAg nanoparticles supported on Vulcan in a glucose laminar membraneless microfuel cell," Journal of Power Sources, vol. 196, no. 14, pp. 5853-5857, 2011.

[14] M. Guerra-Balcázar, F. M. Cuevas-Muñiz, F. Castaneda et al., "Carbon nanotubes as catalyst support in a glucose microfluidic fuel cell in basic media," Electrochimica Acta, vol. 56, no. 24, pp. 8758-8762, 2011.

[15] M. Meena Kumari, J. Jacob, and D. Philip, "Green synthesis and applications of Au-Ag bimetallic nanoparticles," Spectrochimica Acta Part A: Molecular and Biomolecular Spectroscopy, vol. 137, pp. 185-192, 2015.

[16] Y. Feng, H. Yin, A. Wang, and W. Xue, "Selectively catalytic oxidation of 1,2-propanediol to lactic, formic, and acetic acids over Ag nanoparticles under mild reaction conditions," Journal of Catalysis, vol. 326, pp. 26-37, 2015.

[17] D. Marković, Z. Šaponjić, M. Radoičić et al., "Sonophotocatalytic degradation of dye C.I. Acid Orange 7 by $\mathrm{TiO}_{2}$ and $\mathrm{Ag}$ nanoparticles immobilized on corona pretreated polypropylene non-woven fabric," Ultrasonics Sonochemistry, vol. 24, pp. 221229, 2015.

[18] K. Tian, S. Alex, G. Siegel, and A. Tiwari, "Enzymatic glucose sensor based on $\mathrm{Au}$ nanoparticle and plant-like $\mathrm{ZnO}$ film modified electrode," Materials Science and Engineering C, vol. 46, pp. 548-552, 2015.

[19] A. Samphao, P. Butmee, J. Jitcharoen, L. Švorc, G. Raber, and K. Kalcher, "Flow-injection amperometric determination of glucose using a biosensor based on immobilization of glucose oxidase onto Au seeds decorated on core $\mathrm{Fe}_{3} \mathrm{O}_{4}$ nanoparticles," Talanta, vol. 142, pp. 35-42, 2015.

[20] N. German, A. Kausaite-Minkstimiene, A. Ramanavicius, T. Semashko, R. Mikhailova, and A. Ramanaviciene, "The use of different glucose oxidases for the development of an amperometric reagentless glucose biosensor based on gold nanoparticles covered by polypyrrole," Electrochimica Acta, vol. 169, pp. 326-333, 2015.

[21] X. Wang, X. Li, C. Luo, M. Sun, L. Li, and H. Duan, "Ultrasensitive molecularly imprinted electrochemical sensor based on magnetism graphene oxide/ $\beta$-cyclodextrin/Au nanoparticles composites for chrysoidine analysis," Electrochimica Acta, vol. 130, pp. 519-525, 2014.
[22] M. Harutal, H. Kageyama, N. Kamijo, T. Kobayashi, and F. Delannay, "Fine structure of novel gold catalysts prepared by coprecipitation," Studies in Surface Science and Catalysis, vol. 44, pp. 33-42, 1989.

[23] J. M. Gottfried, K. J. Schmidt, S. L. M. Schroeder, and K. Christmann, "Adsorption of carbon monoxide on $\mathrm{Au}\left(\begin{array}{lll}1 & 1 & 0)-(1\end{array}\right.$ $\times 2$ )," Surface Science, vol. 536, no. 1-3, pp. 206-224, 2003.

[24] M. S. El-Deab, T. Sotomura, and T. Ohsaka, "Oxygen reduction at electrochemically deposited crystallographically oriented Au (100)-like gold nanoparticles," Electrochemistry Communications, vol. 7, no. 1, pp. 29-34, 2005.

[25] M. Guerra-Balcázar, J. Torres-González, I. Terol-Villalobos, J. Morales-Hernández, and F. Castañeda, "Glassy carbon electrode-supported au nanoparticles for the glucose electrooxidation: on the role of crystallographic orientation," Journal of Nanomaterials, vol. 2012, Article ID 387581, 8 pages, 2012.

[26] T. N. Huan, S. Kim, P. Van Tuong, and H. Chung, "AuAg bimetallic nanodendrite synthesized via simultaneous coelectrodeposition and its application as a SERS substrate," RSC Advances, vol. 4, no. 8, pp. 3929-3933, 2014.

[27] C. Gao, Y. Hu, M. Wang, M. Chi, and Y. Yin, "Fully alloyed $\mathrm{Ag} / \mathrm{Au}$ nanospheres: combining the plasmonic property of $\mathrm{Ag}$ with the stability of Au," Journal of the American Chemical Society, vol. 136, no. 20, pp. 7474-7479, 2014.

[28] Y. Cui, B. Ren, J.-L. Yao, R.-A. Gu, and Z.-Q. Tian, "Synthesis of $\mathrm{Ag}_{\text {core }} \mathrm{Au}_{\text {shell }}$ bimetallic nanoparticles for immunoassay based on surface-enhanced Raman spectroscopy," The Journal of Physical Chemistry B, vol. 110, no. 9, pp. 4002-4006, 2006.

[29] S. E. Hunyadi and C. J. Murphy, "Bimetallic silver-gold nanowires: fabrication and use in surface-enhanced Raman scattering," Journal of Materials Chemistry, vol. 16, no. 40, pp. 3929-3935, 2006.

[30] F. Xiao, F. Zhao, D. Mei, Z. Mo, and B. Zeng, "Nonenzymatic glucose sensor based on ultrasonic-electrodeposition of bimetallic PtM ( $\mathrm{M}=\mathrm{Ru}, \mathrm{Pd}$ and $\mathrm{Au})$ nanoparticles on carbon nanotubes-ionic liquid composite film," Biosensors and Bioelectronics, vol. 24, no. 12, pp. 3481-3486, 2009.

[31] J. Suntivich, Z. Xu, C. E. Carlton et al., "Surface composition tuning of Au-Pt bimetallic nanoparticles for enhanced carbon monoxide and methanol electro-oxidation," Journal of the American Chemical Society, vol. 135, no. 21, pp. 7985-7991, 2013.

[32] H. Zhang, M. Haba, M. Okumura, T. Akita, S. Hashimoto, and $\mathrm{N}$. Toshima, "Novel formation of $\mathrm{Ag} / \mathrm{Au}$ bimetallic nanoparticles by physical mixture of monometallic nanoparticles in dispersions and their application to catalysts for aerobic glucose oxidation," Langmuir, vol. 29, no. 33, pp. 10330-10339, 2013.

[33] H. Yu and Y. He, "Seed-assisted synthesis of dendritic Au-Ag bimetallic nanoparticles with chemiluminescence activity and their application in glucose detection," Sensors and Actuators B: Chemical, vol. 209, pp. 877-882, 2015.

[34] J. Huang, S. Vongehr, S. Tang, H. Lu, J. S. And, and X. Meng, "Ag dendrite-based au/ag bimetallic nanostructures with strongly enhanced catalytic activity," Langmuir, vol. 25, no. 19, pp. 1189011896, 2009.

[35] J. N. Chheda, G. W. Huber, and J. A. Dumesic, "Liquidphase catalytic processing of biomass-derived oxygenated hydrocarbons to fuels and chemicals," Angewandte ChemieInternational Edition, vol. 46, no. 38, pp. 7164-7183, 2007.

[36] H. Zhang, T. Watanabe, M. Okumura, M. Haruta, and N. Toshima, "Catalytically highly active top gold atom on palladium nanocluster," Nature Materials, vol. 11, no. 1, pp. 49-52, 2012. 
[37] S. Biella, L. Prati, and M. Rossi, "Selective oxidation of Dglucose on gold catalyst," Journal of Catalysis, vol. 206, no. 2, pp. 242-247, 2002.

[38] T. Ishida, N. Kinoshita, H. Okatsu, T. Akita, T. Takei, and M. Haruta, "Influence of the support and the size of gold clusters on catalytic activity for glucose oxidation," Angewandte Chemie International Edition, vol. 47, no. 48, pp. 9265-9268, 2008.

[39] C. Jin and Z. Chen, "Electrocatalytic oxidation of glucose on gold-platinum nanocomposite electrodes and platinummodified gold electrodes," Synthetic Metals, vol. 157, no. 13-15, pp. 592-596, 2007.

[40] M. Tominaga, T. Shimazoe, M. Nagashima, and I. Taniguchi, "Composition-activity relationships of carbon electrode-supported bimetallic gold-silver nanoparticles in electrocatalytic oxidation of glucose," Journal of Electroanalytical Chemistry, vol. 615, no. 1, pp. 51-61, 2008.

[41] N. German, A. Ramanavicius, J. Voronovic, and A. Ramanaviciene, "Glucose biosensor based on glucose oxidase and gold nanoparticles of different sizes covered by polypyrrole layer," Colloids and Surfaces A: Physicochemical and Engineering Aspects, vol. 413, pp. 224-230, 2012.

[42] L. Liu, X. Zhang, and J. Chaudhuri, "Size control in the synthesis of 1-6 nm gold nanoparticles using folic acid-chitosan conjugate as a stabilizer," Materials Research Express, vol. 1, no. 3, p. 035033 , 2014.

[43] X. Zhang, Y. L. Chen, R.-S. Liu, and D. P. Tsai, "Plasmonic photocatalysis," Reports on Progress in Physics, vol. 76, no. 4, Article ID 046401, 41 pages, 2013.

[44] S. Link and M. A. El-Sayed, "Spectral properties and relaxation dynamics of surface plasmon electronic oscillations in gold and silver nanodots and nanorods," The Journal of Physical Chemistry B, vol. 103, no. 40, pp. 8410-8426, 1999.

[45] Y. Tian and T. Tatsuma, "Mechanisms and applications of plasmon-induced charge separation at $\mathrm{TiO}_{2}$ films loaded with gold nanoparticles," Journal of the American Chemical Society, vol. 127, no. 20, pp. 7632-7637, 2005.

[46] S. M. Yoo, S. B. Rawal, J. E. Lee et al., "Size-dependence of plasmonic Au nanoparticles in photocatalytic behavior of $\mathrm{Au} / \mathrm{TiO}_{2}$ and $\mathrm{Au} @ \mathrm{SiO}_{2} / \mathrm{TiO}_{2}$," Applied Catalysis A: General, vol. 499, pp. 47-54, 2015.

[47] R. Kuladeep, L. Jyothi, K. S. Alee, K. L. N. Deepak, and D. N. Rao, "Laser-assisted synthesis of Au-Ag alloy nanoparticles with tunable surface plasmon resonance frequency," Optical Materials Express, vol. 2, no. 2, pp. 161-172, 2012.

[48] A. Pal, S. Shah, and S. Devi, "Preparation of silver-gold alloy nanoparticles at higher concentration using sodium dodecyl sulfate," Australian Journal of Chemistry, vol. 61, no. 1, pp. 66-71, 2008.

[49] H. Quan, S.-U. Park, and J. Park, "Electrochemical oxidation of glucose on silver nanoparticle-modified composite electrodes," Electrochimica Acta, vol. 55, no. 7, pp. 2232-2237, 2010.

[50] P. Stonehart and F. P. Portante, "Potentiodynamic examination of surface processes and kinetics for the $\mathrm{Ag}_{2} \mathrm{O} / \mathrm{AgO} / \mathrm{OH}^{-}$ system," Electrochimica Acta, vol. 13, no. 8, pp. 1805-1814, 1968.

[51] Q. Shi, G. Diao, and S. Mu, "The electrocatalytic oxidation of glucose on the bimetallic Au-Ag particles-modified reduced graphene oxide electrodes in alkaline solutions," Electrochimica Acta, vol. 133, pp. 335-346, 2014.

[52] L. D. Burke, "Premonolayer oxidation and its role in electrocatalysis," Electrochimica Acta, vol. 39, no. 11-12, pp. 1841-1848, 1994.
[53] J. Wang, J. Gong, Y. Xiong et al., "Shape-dependent electrocatalytic activity of monodispersed gold nanocrystals toward glucose oxidation," Chemical Communications, vol. 47, no. 24, pp. 6894-6896, 2011.

[54] L. Y. Chen, T. Fujita, Y. Ding, and M. W. Chen, "A threedimensional gold-decorated nanoporous copper core-shell composite for electrocatalysis and nonenzymatic biosensing," Advanced Functional Materials, vol. 20, no. 14, pp. 2279-2285, 2010.

[55] Z. Borkowska, A. Tymosiak-Zielinska, and G. Shul, "Electrooxidation of methanol on polycrystalline and single crystal gold electrodes," Electrochimica Acta, vol. 49, no. 8, pp. 1209-1220, 2004.

[56] J. Wang, X. Cao, X. Wang, S. Yang, and R. Wang, "Electrochemical oxidation and determination of glucose in alkaline media based on $\mathrm{Au}$ (111)-like nanoparticle array on indium tin oxide electrode," Electrochimica Acta, vol. 138, pp. 174-186, 2014.

[57] Y. L. Mikhlin, E. A. Vishnyakova, A. S. Romanchenko et al., "Oxidation of Ag nanoparticles in aqueous media: effect of particle size and capping," Applied Surface Science, vol. 297, pp. 75-83, 2014. 

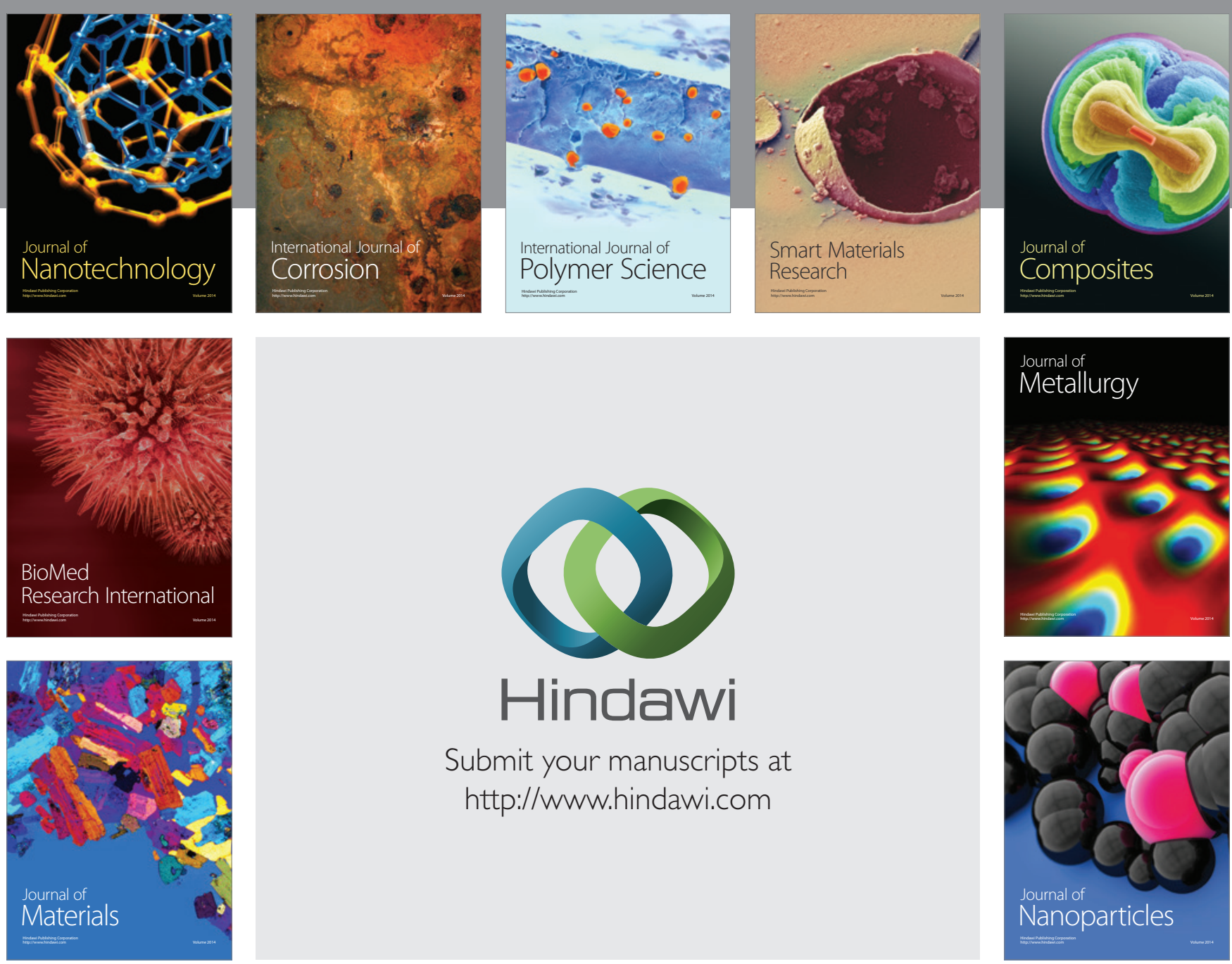

Submit your manuscripts at http://www.hindawi.com
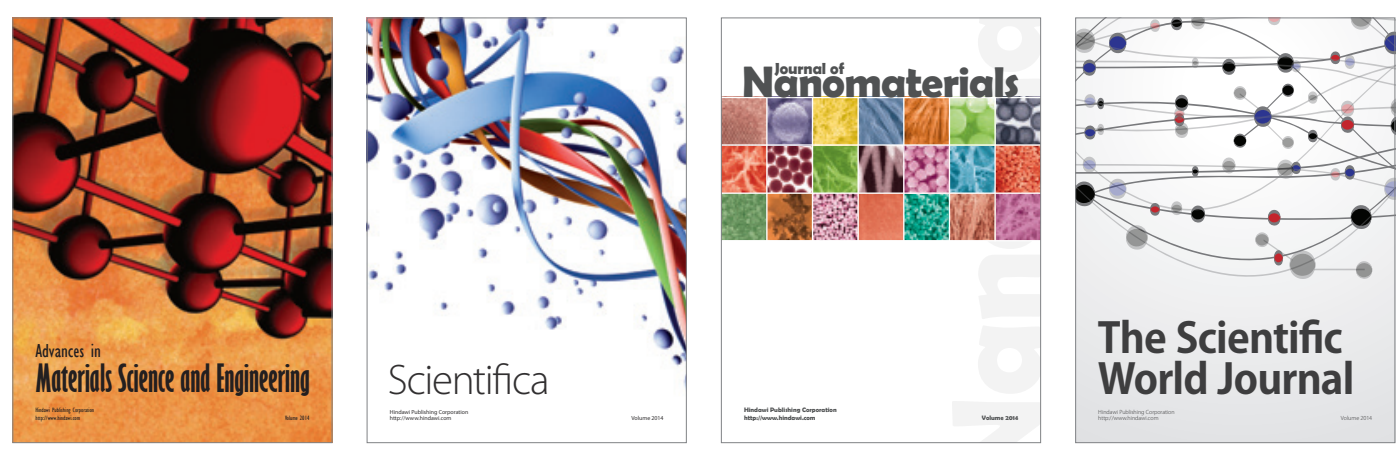

\section{The Scientific World Journal}
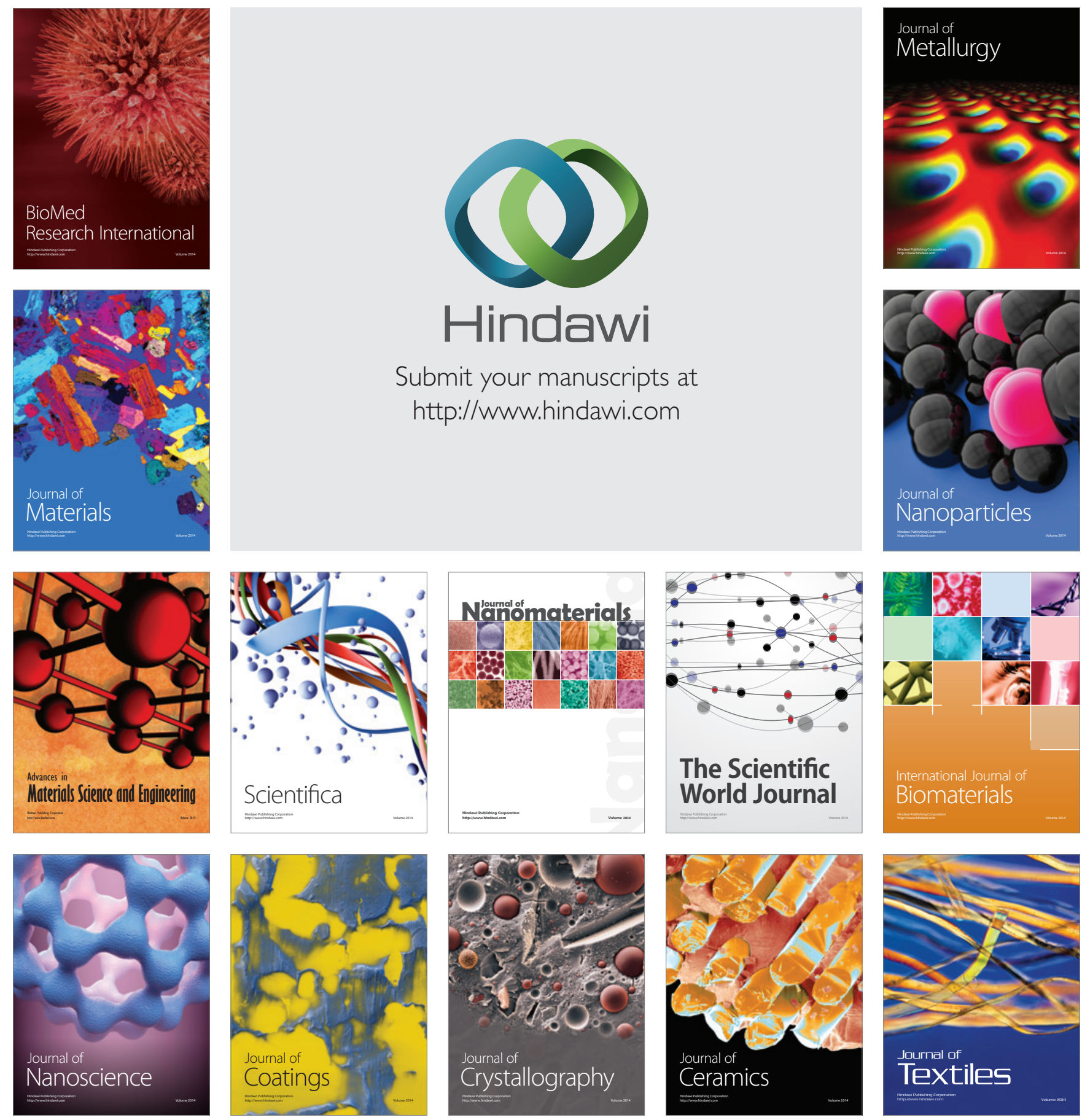